\title{
Volatile compounds and sensory properties of Montasio cheese made from the milk of Simmental cows grazing on alpine pastures
}

\author{
S. Bovolenta, ${ }^{*}$ A. Romanzin, ${ }^{* 1}$ M. Corazzin, ${ }^{*}$ M. Spanghero, ${ }^{*}$ E. Aprea, $†$ F. Gasperi, $†$ and E. Piasentier* \\ *Department of Agriculture and Environmental Science, University of Udine, Via delle Scienze 206, 33100 Udine, Italy \\ †Department of Food Quality and Nutrition, Research and Innovation Centre, Fondazione Edmund Mach (FEM), Via E. Mach, 1, \\ 38010 San Michele all'Adige, Italy
}

\section{ABSTRACT}

The aim of this study was to analyze the volatile compounds, physicochemical characteristics, and sensory properties of Montasio, a semicooked pressed cheese, produced from the milk of the dual-purpose Italian Simmental cows grazing on alpine pastures. A total of 72 cows grazing on 2 pastures, which differed in botanical composition (nutrient-rich pasture vs. nutrient-poor pasture), received 2 different levels of supplementation (3.0 vs $1.5 \mathrm{~kg} /$ head per day). The experimental cheeses were produced from whole, raw milk and ripened for $60 \mathrm{~d}$. Sixty-one volatile compounds, including alcohols (11), aldehydes (6), ketones (10), lactones (2), esters (6), hydrocarbons (3), carboxylic acids (6), phenolic compounds (4), monoterpenes (7), sesquiterpenes (1), sulfur compounds (4), and amines (1), were detected. The main families in terms of relative weight appeared to be carboxylic acids, esters, and alcohols. A panel of trained assessors described the experimental cheeses as having an intense color; small and evenly distributed eyes; an intense odor and flavor of milk-sour, milk, and cow; and a tender and creamy texture. The pasture type affected the volatile fraction, particularly ketones, phenolic compounds, and terpenes, which are overall higher in nutrient-poor pastures. A slight effect on the sensory analyses, in particular the effect of the cow attribute on odor and flavor, was perceived by the panelists. The cheeses produced on nutrient-rich pasture had higher $\mathrm{b}^{*}$ (yellowness) index. These results were consistent with the color evaluation of the sensory panel. In addition, the pasture affected some textural attributes (adhesivity, creaminess, and granules) as perceived by the panelists. Concentrate supplementation, which is required to meet the feeding requirements of grazing cows, had no clear effect on either the volatile compounds or the sensory properties of the cheeses. Thus, at least within levels of integration adopted, it is ex-

Received May 21, 2014.

Accepted August 23, 2014.

${ }^{1}$ Corresponding author: alberto.romanzin@uniud.it pected not to alter the organoleptic characteristics of this product.

Key words: Montasio cheese, Italian Simmental cow, mountain pasture, volatile compound, sensory property

\section{INTRODUCTION}

The Alps are characterized by a great variety of environments and socioeconomic situations that have created the conditions for the production of a large number of dairy products, which are strongly linked to local resource utilization (Hauwuy et al., 2006; Boni and Seidl, 2012). In this context, cattle husbandry is traditionally based on small herds of local dual-purpose breeds. During the cold seasons, the animals are housed in barns and fed with local hay-based diet, whereas in summer they are moved to high-altitude pastures (Sturaro et al., 2013; Battaglini et al., 2014). When the herbage is not sufficient to cover the nutritional requirements of the animals, an adequate supplementation with concentrates is often provided.

Several studies have shown that the floristic diversity of grazed herbage can influence the sensory characteristics of raw milk cheese, particularly for the direct or indirect effect of volatile compounds present in the different grass species (Buchin et al., 1999; Bugaud et al., 2001; De Noni and Battelli, 2008). Among the many factors that may influence this effect, concentrate supplementation could have an important role. This aspect has been studied little; nevertheless, the supplements may modify the quantity and quality of herbage intake (Peyraud and Delaby, 2001; Bovolenta et al., 2005, 2009) and the metabolic pathways that, starting from the rumen, lead to the formation of volatile compounds (Nagaraja, 2012).

The floral composition of pastures is, in turn, strongly related to the environmental conditions and is part of the terroir, a concept at the basis of the protected designation of origin (PDO) labels (Barham, 2003). Therefore, it is generally accepted that the volatile profile is a type of fingerprint that can be used to characterize dairy products, defining their links to the area 
and methodology of production. Many studies have reported the volatile profiles of several mountain PDO cheeses, such as Gruyère (Rychlik and Bosset, 2001), Emmental (Pillonel et al., 2003), Abondance (Buchin et al., 1999; Bugaud et al., 2001), Cantal (Tornambé et al., 2008; Cornu et al., 2009), Fontina (Berard et al., 2007), Bitto (Panseri et al., 2008), and Trentingrana (Endrizzi et al., 2012; Franciosi et al., 2012).

Cheese aroma is the result of complex interactions between a large variety of compounds present in different concentrations; often those with lower detection thresholds contribute the most to the odor and flavor (Thomsen et al., 2012). Sensory science provides standardized techniques to determine the characteristics perceived by the senses and to study consumer behavior. In particular, discriminant or descriptive analyses can be used for this purpose (Drake, 2007).

Therefore, the present study is aimed to analyze the volatile compounds, physicochemical characteristics, and sensory properties of Montasio PDO cheese produced from the milk of the dual-purpose Italian Simmental cows grazing on different alpine pastures. In addition, different levels of concentrate supplement were considered. Montasio is one of the most important PDO cheeses produced in northeast Italy, and, although it takes its name from a mountain plateau, it is produced largely in the lowlands. Recently, to valorize mountain cheese and link it to the most common breed in this area, the production of PDO Montasio was combined with 2 additional labels: "Prodotto della Montagna" (mountain product) and "Solo di Pezzata Rossa Italiana" (only Italian Simmental breed; Romanzin et al., 2013).

\section{MATERIALS AND METHODS}

\section{Experimental Design and Treatments}

The experiment was conducted in an alpine farm (Malga Montasio, Udine, Italy; $46^{\circ} 24^{\prime} 45^{\prime \prime} \mathrm{N}, 13^{\circ} 25^{\prime} 53^{\prime \prime} \mathrm{E}$; altitude $=1,500-1,800 \mathrm{~m}$ ). For the experiment, we selected 2 pastures with different vegetation types. The botanical composition of pastures was estimated by cutting, in each of selected pastures, of 14 strips of 10 $\times 0.10 \mathrm{~m}$ at $0.04 \mathrm{~m}$ in height using electric grass shears. Samples were hand-separated into botanical families. The subsamples were dried in an oven at $70^{\circ} \mathrm{C}$ and underwent a botanical assessment for weight. The first pasture $(1,500 \mathrm{~m}$ above sea level) was a nutrient-rich pasture characterized by $66.5 \%$ Poaceae and Cyperaceae (main species: Poa alpina, Phleum rhaeticum, Festuca rubra), 7.4\% Ranunculaceae (Ranunculus acris), and $2.8 \%$ Fabaceae (Trifolium repens, Trifolium pratense). The second pasture $(1,700 \mathrm{~m}$ above sea level) was a nutrient-poor pasture characterized by $61.8 \%$ Poaceae and Cyperaceae (main species: Sesleria caerulea, Koeleria eriostachya, Carex sempervirens), 8.5\% Asteraceae (Achillea clavennae), 5.4\% Fabaceae (Lotus alpinus), and $3.3 \%$ Rosaceae (Potentilla crantzii).

A total of 72 Italian Simmental cows used first the rich pasture and then the poor pasture. Pastures were grazed at the same phenological stage (flowering period of Poaceae) following the vegetation gradient. Cows were maintained day and night at pasture and assigned to 2 experimental groups according to their mean performance characteristics recorded during a 2 -wk preliminary period (average \pm SD) for milk yield (16.9 $\pm 3.3 \mathrm{~kg} / \mathrm{d})$, stage of lactation $(192.8 \pm 64.0 \mathrm{DIM})$, fat $(3.94 \pm 0.25 \%)$, protein $(3.29 \pm 0.14 \%)$, lactose $(4.71$ $\pm 0.12 \%)$, and SCC $(130,000 \pm 47,000$ cells $/ \mathrm{mL})$. During this period cows received $2.2 \mathrm{~kg} / \mathrm{head}$ per day on average of supplement (commercial mixed concentrate based on maize, barley, beet pulp, soy, and wheat). During a 10-d experimental period, 36 cows (high group) were supplemented with $3 \mathrm{~kg} /$ head per day on average of the same concentrate. The other 36 cows (low group) were supplemented with $1.5 \mathrm{~kg} /$ head per day on average of concentrate. The supplement was given twice a day during milking.

Chemical composition and nutritive value of pastures and concentrate used are shown in Table 1. Samples were analyzed for $\mathrm{CP}$ and ether extract according to AOAC International (2000), and for NDF according to Goering and Van Soest (1970). The nutritive value, expressed in $\mathrm{NE}_{\mathrm{L}}$, was estimated according to INRA standards (Baumont et al., 2010).

\section{Cheese Manufacture}

The experimental cheeses were produced from whole and raw milk from 2 consecutive milkings. The evening milk, cooled to $8^{\circ} \mathrm{C}$, was pooled with milk from the following morning. Cheese making was repeated for the last 3 consecutive days ( $\mathbf{R} \mathbf{1}, \mathbf{R} \mathbf{2}$, and $\mathbf{R} \mathbf{3})$ of the experimental period for each experimental group (12 cheese-making sessions) in accordance with the product specification of PDO Montasio. Milk was heated to $32^{\circ} \mathrm{C}$ in a stainless steel vat (capacity $1 \mathrm{t}$ ), and then a natural starter culture was added in milk to drive the primary fermentation. This milk natural culture, achieved by incubating raw milk (previously heated for $1 \mathrm{~min}$ at $68^{\circ} \mathrm{C}$ ) overnight at $45^{\circ} \mathrm{C}$, was added at the level of $10 \mathrm{~g} / \mathrm{kg}$ of milk and processed the next day. After $20 \mathrm{~min}$ of incubation, $0.1 \mathrm{~g} / \mathrm{kg}$ of milk rennet (Clerici Sacco, 96\% chymosin; 1,000 international milk clotting units (IMCU)/g) was added. The curd was cut to obtain pellets of size comparable to grain of rice, cooked at $45^{\circ} \mathrm{C}$ for $20 \mathrm{~min}$, and stirred out for 
Table 1. Mean chemical composition and nutritive value of herbage allowed and supplement

\begin{tabular}{lccc}
\hline & \multicolumn{3}{c}{ Herbage } \\
\cline { 2 - 3 } Item & Rich & Poor & Supplement \\
\hline $\mathrm{CP}, \%$ of DM & 12.9 & 11.2 & 14.7 \\
Ether extract, \% of DM & - & - & 2.7 \\
Ash, \% of DM & 5.9 & 5.6 & 4.9 \\
$\mathrm{NDF}, \%$ of $\mathrm{DM}$ & 53.8 & 53.9 & 7.76 \\
$\mathrm{NE}_{\mathrm{L}}, \mathrm{MJ} / \mathrm{kg}$ of $\mathrm{DM}$ & 5.60 & 5.37 & 7.76 \\
\hline
\end{tabular}

30 min. Then the curd was removed from the vat with a cloth, placed into molds, and pressed for $24 \mathrm{~h}$. Fresh cheeses were then placed in brine for $48 \mathrm{~h}(18 \%$ salt concentration). Cheese shape was cylindrical, about 6 $\mathrm{kg}$ of weight and $70 \mathrm{~mm}$ in height. Three shapes for each cheese making were ripened for $60 \mathrm{~d}$ in a ripening cellar with controlled temperature $\left(12^{\circ} \mathrm{C}\right)$ and humidity $(85 \%)$ until sampled for analysis.

\section{Chemical and Physical Analysis}

The chemical analyses were carried out at the end of the ripening period on samples of grated cheese, after removing $10 \mathrm{~mm}$ of rind. They were analyzed for DM, fat, and protein contents according to the AOAC International (2000) methods.

A chroma-meter (CR 400, Minolta, Osaka, Japan) was used for measuring colorimetric parameters: lightness $\left(\mathrm{L}^{*}\right)$, redness $\left(\mathrm{a}^{*}\right)$, and yellowness $\left(\mathrm{b}^{*}\right)$ using the CIE standard illuminant D65. Color was measured on 6 different points on the just-cut cheese slice surface and values were averaged. A metallic grid, $120 \times 60 \mathrm{~mm}$, was used to ensure the reproducibility of the sampling points.

The rheological properties of cheeses were evaluated with a texture analyzer (TA Plus, Lloyd Instruments, Bognor Regis, UK) using the procedure described by Gunasekaran and Ak (2003). Texture profile analysis was applied on the cylindrical samples of cheese $(20$ $\mathrm{mm}$ in diameter and $20 \mathrm{~mm}$ in height) compressed axially in 2 consecutive cycles, with a deformation of $50 \%$ of the original height and applying a force of $100 \mathrm{~mm} /$ min. The rheological parameters analyzed were hardness, cohesiveness, adhesiveness, springiness, gumminess, and chewiness.

\section{Headspace Analysis by Solid-Phase Microextraction GC-MS}

Samples were analyzed according the solid-phase microextraction (SPME) GC-MS technique based on the procedure described by Endrizzi et al. (2012). Briefly, $3 \mathrm{~g}$ of grated cheese were placed in glass vials $(20 \mathrm{~mL}$,
Supelco, Bellefonte, PA) adding $4 \mathrm{~mL}$ of bi-distilled water, $50 \mu \mathrm{l}$ of a solution of 3 internal standards with purity not lower than 99\% (4-methyl-2-pentanone = $0.0509 \mathrm{mg} / \mathrm{mL}$, Aldrich, Milan, Italy; ethyl heptanoate $=0.06 \mathrm{mg} / \mathrm{mL}$, Aldrich; and isobutyric acid $=20.021$ $\mathrm{mg} / \mathrm{mL}$, Fluka, Milan, Italy), and a magnetic stir bar before capping with polytetrafluoroethylene/silicone septa (Supelco).

Cheese samples were equilibrated at $40^{\circ} \mathrm{C}$ under stirring (750 rpm) for $30 \mathrm{~min}$ and then a 2 -cm fused silica fiber coated with divinylbenzene-carboxen-polydimethylsiloxane 50/30 $\mu \mathrm{m}$ (Supelco) was introduced and exposed to the headspace environment for $30 \mathrm{~min}$. Volatile compounds concentrated on the SPME fiber were desorbed at $250^{\circ} \mathrm{C}$ in the injector port of a $\mathrm{GC}$ interfaced with a mass detector which operates in electron ionization mode (internal ionization source; $70 \mathrm{eV}$ ) with a scan range from 30 to $300 \mathrm{~m} / z$ (GC Clarus 500, PerkinElmer, Norwalk, CT). Procedure phases were automatically managed by using a self-sampling system (CTC combiPAL, CTC Analysis AG, Zwingen, Switzerland). Separation was achieved on a HP-Innowax fused-silica capillary column $(30 \mathrm{~m}, 0.32 \mathrm{~mm}$ internal diameter, $0.5 \mu \mathrm{m}$ film thickness; Agilent Technologies, Palo Alto, CA). The GC oven temperature program consisted of $40^{\circ} \mathrm{C}$ for $3 \mathrm{~min}, 40$ to $180^{\circ} \mathrm{C}$ at $4^{\circ} \mathrm{C} / \mathrm{min}$, $180^{\circ} \mathrm{C}$ for $6 \mathrm{~min}$, and 180 to $220^{\circ} \mathrm{C}$ at $5^{\circ} \mathrm{C} / \mathrm{min}$. Helium was used as carrier gas with a constant column flow rate of $2 \mathrm{~mL} / \mathrm{min}$. Compound identification was based on mass spectra matching with the standard Wiley and NIST MS library (McLafferty, 2006) and retention indices of authentic reference standards compared with those found in literature. Results are reported as micrograms per kilogram equivalent to the internal standard (ethyl heptanoate for the esters; isobutyric acid for the carboxylic acids; 4-methyl-2-pentanone for all the other compounds). The 3 standards were chosen to partially compensate for the different fiber compounds' responses to different classes of compounds. To test the repeatability of the method, 8 replicates of a reference sample prepared by homogenizing different cheese samples from the trial were analyzed. The observed max variation $(5,13,7,13,12$, and $13 \%$ for 
the classes of acids, alcohols, esters, ketones, aldehydes, and sulfur compounds, respectively) is in agreement with the literature for SPME analysis with this type of matrix (Endrizzi et al., 2012).

\section{Descriptive Sensory Analysis}

A 10-member panel was trained according to specific procedures for the sensory evaluation of hard and semihard cheese (ISO, 2009a,b,c) and experienced in quantitative descriptive analysis of typical semihard cheeses. During training, the panel developed a profile protocol for a quantitative descriptive method containing 26 attributes related to visual appearance (6 attributes), odor (5), texture (4), taste (6), and flavor (5; Table 2). The panel was first presented cheeses having sensory characteristic extremes for each term, representing the anchors of each scale, and second more common semihard cheeses; scores were assigned to these cheeses through panel consensus. Through training and group discussion, panel variability was minimized.

Sensory profiling was performed in a laboratory built according to the UNI EN ISO (UNI, 2010) standard. The panel rated the intensity of each sensory attribute on a 100-mm unstructured scale, anchored at each end. Six cheeses ( 1 for each production day and for each of the 2 supplement levels) produced from rich pasture and a standard cheese (a commercial type of PDO Montasio cheese) were assessed by trained judges 3 times in 3 successive sessions using randomized block design to minimize carry over effects. The same procedure was followed to evaluate the cheeses produced from poor pasture. The standard cheese was used to allow the comparison between the 2 pastures. Samples were presented at room temperature $\left(20^{\circ} \mathrm{C} \pm 2\right)$ as small fingers, wrapped in aluminum foil, measuring 15 $\times 15 \mathrm{~mm}$ in thickness and $50 \mathrm{~mm}$ long. Samples were identified using random 3-digit numerical code.

\section{Statistical Analysis}

The statistical analysis was performed using SPSS for Windows (version 7.5.21, SPSS Inc., Chicago, IL). Normality of data distribution and homogeneity of variance were tested using Shapiro-Wilks test. Cheese composition and rheological propriety data were subjected to hierarchical model that included the fixed effect of pasture (rich, poor) and supplement level

Table 2. List of sensory attributes measured by the expert panel

\begin{tabular}{|c|c|}
\hline Item & Description \\
\hline \multicolumn{2}{|l|}{ Visual appearance } \\
\hline Eyes, diameter & Average diameter of the eyes ${ }^{1}$ \\
\hline Eyes, shape regularity & Regularity in the shape of eyes ${ }^{1}$ \\
\hline Eyes, distribution regularity & Regularity in the distribution of eyes in the surface ${ }^{1}$ \\
\hline Color intensity & Intensity of yellow competent in the surface color ${ }^{2}$ \\
\hline Rind height & Height of the ring ${ }^{2}$ \\
\hline Elasticity & The rapidity of recovering initial thickness after a deforming pressure with the thumb ${ }^{2}$ \\
\hline \multicolumn{2}{|r|}{ 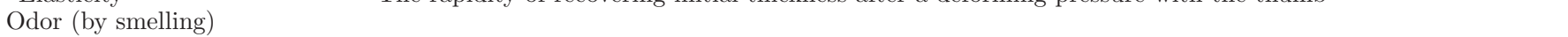 } \\
\hline Milk & The odor associated with fresh cream-milk (pasteurized cream $35 \%$ fat) \\
\hline Sour milk & The odor associated with sour milk products (not fat yogurt) \\
\hline Cow & The odor associate with cattle (straw layer from cattle) \\
\hline Ammonia & The odor associated with ammonia (fresh milk aromatized with $500 \mathrm{mg} / \mathrm{L}$ of $\mathrm{NH}_{4} \mathrm{OH}$ ) \\
\hline Herbage & The odor associated with the freshly cut green herbage \\
\hline \multicolumn{2}{|r|}{ E- } \\
\hline Sweet & The basic taste sensation related to fructose added in ricotta cheese $(30 \mathrm{~g} / \mathrm{kg})$ \\
\hline Salty & The basic taste sensation related to sodium chloride added in ricotta $(6 \mathrm{~g} / \mathrm{kg})$ \\
\hline Umami & Chemical feeling factor related to specific peptides and nucleotides (monosodium glutamate, $1 \%$ in water) \\
\hline Acid & The basic taste sensation related to lactic acid added in ricotta $(5 \mathrm{~g} / \mathrm{kg})$ \\
\hline Bitter & The basic taste sensation related to caffeine added in ricotta $(0.2 \mathrm{~g} / \mathrm{kg})$ \\
\hline Pungent & The burning sensation of tongue and mouth surface related to capsaicin added in ricotta cheese $(20 \mathrm{mg} / \mathrm{kg})$ \\
\hline \multicolumn{2}{|r|}{ 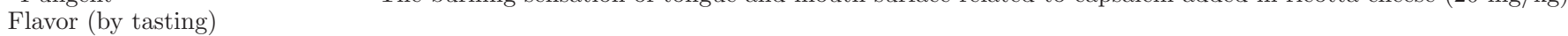 } \\
\hline Milk & The flavor associated with fresh cream-milk (pasteurized cream 35\% fat) \\
\hline Sour milk & The flavor associated with sour milk products (not fat natural yogurt) \\
\hline Cow & The flavor associated with cattle (straw layer from cattle) \\
\hline Ammonia & The flavor associated with ammonia (fresh milk aromatized with $500 \mathrm{mg} / \mathrm{kg}$ of $\mathrm{NH}_{4} \mathrm{OH}$ ) \\
\hline Herbage & The flavor associated with the freshly cut green herbage \\
\hline \multicolumn{2}{|l|}{ Texture } \\
\hline Tenderness & The force required to bite with molar the sample cube (first bite) \\
\hline Adhesivity & The force required to unstick from teeth the chewed cheese (after 8 acts of chewing) \\
\hline Creaminess & The ability of sample to create a cream during chewing \\
\hline Granules & The degree of the consistency of particles in the mouth (after 8 acts of chewing) \\
\hline
\end{tabular}

${ }^{1}$ Evaluated on a photo of a 10- $\times 5$-cm sector of inner surface of cheese (by scanner).

${ }^{2}$ Evaluated on the cheese sample. 
Table 3. Chemical composition and physical properties of cheeses

\begin{tabular}{|c|c|c|c|c|c|c|c|}
\hline \multirow[b]{2}{*}{ Item } & \multicolumn{2}{|c|}{ Pasture } & \multicolumn{2}{|c|}{ Supplement } & \multirow[b]{2}{*}{ SEM } & \multicolumn{2}{|c|}{ Significance $^{1}$} \\
\hline & Rich & Poor & High & Low & & $\mathrm{P}$ & S \\
\hline \multicolumn{8}{|l|}{ Chemical composition } \\
\hline DM, \% & 66.3 & 66.9 & 66.3 & 66.9 & 0.21 & 0.20 & 0.19 \\
\hline Fat, $\%$ of DM & 52.7 & 53.7 & 53.1 & 53.3 & 0.36 & 0.18 & 0.71 \\
\hline Protein, $\%$ of DM & 41.3 & 39.7 & 41.3 & 39.6 & 0.40 & 0.07 & 0.07 \\
\hline \multirow{2}{*}{\multicolumn{8}{|c|}{ Color $^{2}$}} \\
\hline & & & & & & & \\
\hline $\mathrm{L}^{*}$ & 79.5 & 78.6 & 78.9 & 79.1 & 0.64 & 0.31 & 0.68 \\
\hline$a^{*}$ & -3.3 & -3.3 & -3.2 & -3.4 & 0.05 & 0.71 & $<0.01$ \\
\hline $\mathrm{b}^{*}$ & 23.5 & 22.0 & 22.8 & 22.7 & 0.21 & 0.03 & 0.55 \\
\hline \multicolumn{8}{|l|}{ Texture } \\
\hline Hardness, N & 48.7 & 55.1 & 52.6 & 51.3 & 1.17 & 0.02 & 0.60 \\
\hline Cohesiveness & 0.58 & 0.57 & 0.58 & 0.57 & 0.004 & 0.08 & 0.06 \\
\hline Adhesiveness, $\mathrm{N} \cdot \mathrm{mm}$ & 0.72 & 0.92 & 0.85 & 0.79 & 0.059 & 0.12 & 0.61 \\
\hline Gumminess, $\mathrm{N}$ & 28.5 & 31.3 & 30.7 & 29.1 & 0.82 & 0.13 & 0.34 \\
\hline Chewiness, N·mm & 24.0 & 25.6 & 25.6 & 24.0 & 0.70 & 0.27 & 0.27 \\
\hline Springiness & 0.84 & 0.82 & 0.83 & 0.82 & 0.002 & $<0.01$ & 0.04 \\
\hline
\end{tabular}

(high, low) and the random effect of cheese-making day nested within pasture. Sensory data were analyzed using similar model, with judge treated as random effect. Data were also processed by principal component analysis carried out using The Unscrambler $\mathrm{X}$ version 10.2 (Camo Software AS, Oslo, Norway). Data were mean centered and variables were weighted with $1 / \mathrm{SD}$ and the full cross-validation method was used.

\section{RESULTS AND DISCUSSION}

\section{Chemical Composition and Physical Proprieties}

As shown in Table 3, the pasture composition and supplement level did not significantly affect the chemical composition of the experimental cheeses. However, slight differences were noted in the protein content, with a $P$-value equal to 0.07 for both of the experimental theses. Milk protein content is known to increase with energy supply in the cow diet, without modifications of the casein-to-protein ratio (Malossini et al., 1996). Consequently, it also increases the protein content in the cheese. In the present test, even if the total ingestion of animals was not estimated, cows grazing on rich pasture or receiving the highest level of supplement probably also had a higher energy level of the ration and therefore more protein in cheese. However, these differences were likely too small to significantly alter the protein content of cheese. Bovolenta et al. (2008, 2009), in 2 trials on Brown cows grazing on alpine pastures and fed with different levels of supplementation ( 4.8 vs. 2.4 and 4.8 vs. $1.6 \mathrm{~kg} / \mathrm{OM}$ per day), obtained an effect on the protein content only with the greatest difference in supplementation levels.
Concerning the colorimetric parameters, small color differences were observed in both of the diet pastures (rich vs. poor) and supplement levels (high vs. low), as reported in Table 3 . The cheeses produced on the rich pasture had higher $b^{*}$ index, whereas the cheeses produced with a high supplement level had a higher a* index. Yellow and red colors of milk and cheese highly depend on their carotenoid content. In addition, the concentration of $\beta$-carotene in milk is highly dependent on the concentration of $\beta$-carotene in the diet of lactating cows (Nozière et al., 2006). Whereas the effect of the maturity stage of the grass and the conservation techniques of forages (fresh, hay, or silage) on the concentration of carotenoids is well known, the effect of botanical composition is quite controversial. Tornambé et al. (2010), in a trial on 3 mountain pastures differing in botanical composition, showed that $\beta$-carotene content in milk is only marginally affected by the grassland type. Marino et al. (2014), in a study on 14 Sicilian dairy farms allocated into 2 groups on the basis of pasture type cultivated (rich in Poaceae: $82.8 \%$ ) or spontaneous (poor in Poaceae: 29.2\%), pointed out that spontaneous pasture had higher contents of $\beta$-carotene. In the present study, color differences linked to supplement levels, although significant, are extremely low and difficult to interpret. These results are consistent with the color evaluation of the sensory panel, which indicated that the samples from the rich pasture were more intense in color.

Very few differences about the texture parameters of the cheeses (Table 3) were found, which are closely linked to the chemical composition (Innocente et al., 2002) and cheese-making techniques (Maifreni et al., 
2002; Lucey et al., 2003). Only hardness was actually higher in cheeses produced in poor pasture.

\section{Volatile Compounds}

The relative abundance of the volatile compounds (expressed as $\mu \mathrm{g} / \mathrm{kg}$ ), including alcohols (11), aldehydes (6), ketones (10), lactones (2), esters (5), hydrocarbons (3), carboxylic acids (7), phenolic compounds (4), monoterpenes (7), sesquiterpenes (1), sulfur compounds (4), and amines (1), is given in Table 4. A total of 61 volatiles were identified. The largest chemical families were represented by carboxylic acids and esters in terms of relative quantity and by alcohols and ketones in terms of the number of detected volatile compounds. Dovier et al. (2005), in a study performed to compare similar cheeses made with milk from 2 rearing systems (indoor lowland vs. mountain pasture), detected 60 volatile compounds belonging to 10 classes. Some authors have reported only a limited number of volatile compounds in Montasio cheese. Polentarutti et al. (2001), in 60-d-old Montasio cheeses, identified 6 short-chain FA, 2 primary alcohols, and 3 methyl-ketones. Also, Innocente et al. (2013), in Montasio cheese from 60 to $365 \mathrm{~d}$ of ripening, detected only 11 compounds. The considerable variability among trials is probably due to the origin of cheeses and to the different analytical approach.

Alcohols can provide alcoholic and floral notes $(\mathrm{Cu}-$ rioni and Bosset, 2002). In total, 11 different alcohols were identified in 60-d-ripened Montasio cheeses. 2-Butanol and 3-methyl-1-butanol were the most abundant alcohols in the chromatograms of all of the samples. 2-Butanol was identified in a relatively larger amount and is formed when diacetyl is reduced to acetoin by bacterial enzymes from raw milk, thereafter to 2,3-butanediol, to 2-butanone, and finally to 2-butanol (Bontinis et al., 2012). 3-Methyl-1-butanol may be formed by the reduction of 3-methyl-1-butanal through the Strecker degradation of leucine (McSweeney and Sousa, 2000). Innocente et al. (2013), in Montasio cheese from 60 to $365 \mathrm{~d}$ of ripening, verified that alcohols were the most significant contributors to the volatile profile. This compound was found at higher levels in rich than in poor pastures. 2-Nonanol and 2-ethyl hexanol, even if significantly higher in the poor pasture, were detected in low concentrations. The total alcohol contents were similar among the different experimental conditions.

Aldehydes, although represented by 6 compounds, were not very abundant in the chromatogram of the experimental cheeses. In effect, aldehydes are transitory compounds and do not accumulate in cheese because they are quickly transformed into alcohols or the corresponding acids (Hayaloglu et al., 2013). Therefore, a low level of aldehydes indicates a good ripening of the cheese, whereas a high concentration of aldehydes may cause off flavors (Moio and Addeo, 1998). 3-Methylbutanal, which can contribute a malt, oil, or butter aroma to cheese and mainly detected in the cheeses, is formed by the degradation of leucine and was found to be a potent odor-producing compound in different cheese varieties (Curioni and Bosset, 2002; Hayaloglu et al., 2013). The pasture type caused significant differences among some of the detected aldehydes: straight-chain aldehydes, such as acetaldehyde, hexanal, and nonanal as well as benzaldehyde, were significantly higher in the poor pasture, but branched-chain aldehydes were significantly higher in the rich pasture.

Ketones are highly represented in different dairy products. The major ketones in our study were 2-butanone, 2-propanone, diacetyl, 2-heptanone, and acetoin (3-hydroxy-2-butanone). The sum of ketones, as well as the concentration of 2-propanone, diacetyl, 2-heptanone, and 2-undecanone, was significantly higher in the poor pasture, whereas only 2-propanone and diacetyl differed among the different supplementations (higher in the high level). Diacetyl is an important aroma-producing compound in several cheese varieties and can be converted to acetoin, 2,3-butanediol and 2-butanone, which are also important flavor compounds in some cheese varieties (Dimos et al., 1996). Ketones have a low perception threshold, and, in particular, diacetyl and acetoin confer buttery notes to cheeses (Molimard and Spinnler, 1996; Moio and Addeo, 1998).

Two lactones were found in the experimental cheeses: $\gamma$-butyrolactone and $\delta$-octalactone. $\gamma$-Butyrolactone is resulted to be higher in the poor pasture than the rich pasture, whereas none of these compounds was affected by the supplementation level. Lactones are cyclic compounds that are generated by the esterification of hydroxy FA (McSweeney and Sousa, 2000). The different $\gamma$ - and $\delta$-lactones in cheeses such as Camembert are important contributors to aroma due to their fruity notes and low perception thresholds (Kubickova and Grosch, 1998). Lactones, in fact, are generally associated with peach and coconut odor descriptors (Curioni and Bosset, 2002).

Esters were the second most abundant detected chemical group. In particular, the ethyl esters were the main esters, and ethyl butyrate represented more than $50 \%$ of the total measured esters. These volatile compounds derived from enzymatic esterification of free FA, generally high in pasture-derived milk and cheese (Carpino et al., 2004). Esters may contribute to sweet, floral, and fruity notes of cheese flavor, although the perception threshold of these compounds is generally low (Molimard and Spinnler, 1996). Esters contribute to cheese flavor by reducing the sharpness of FA and the 
Table 4. Volatiles $(\mu \mathrm{g} / \mathrm{kg})$ in experimental cheeses by solid-phase microextraction GC-MS analysis

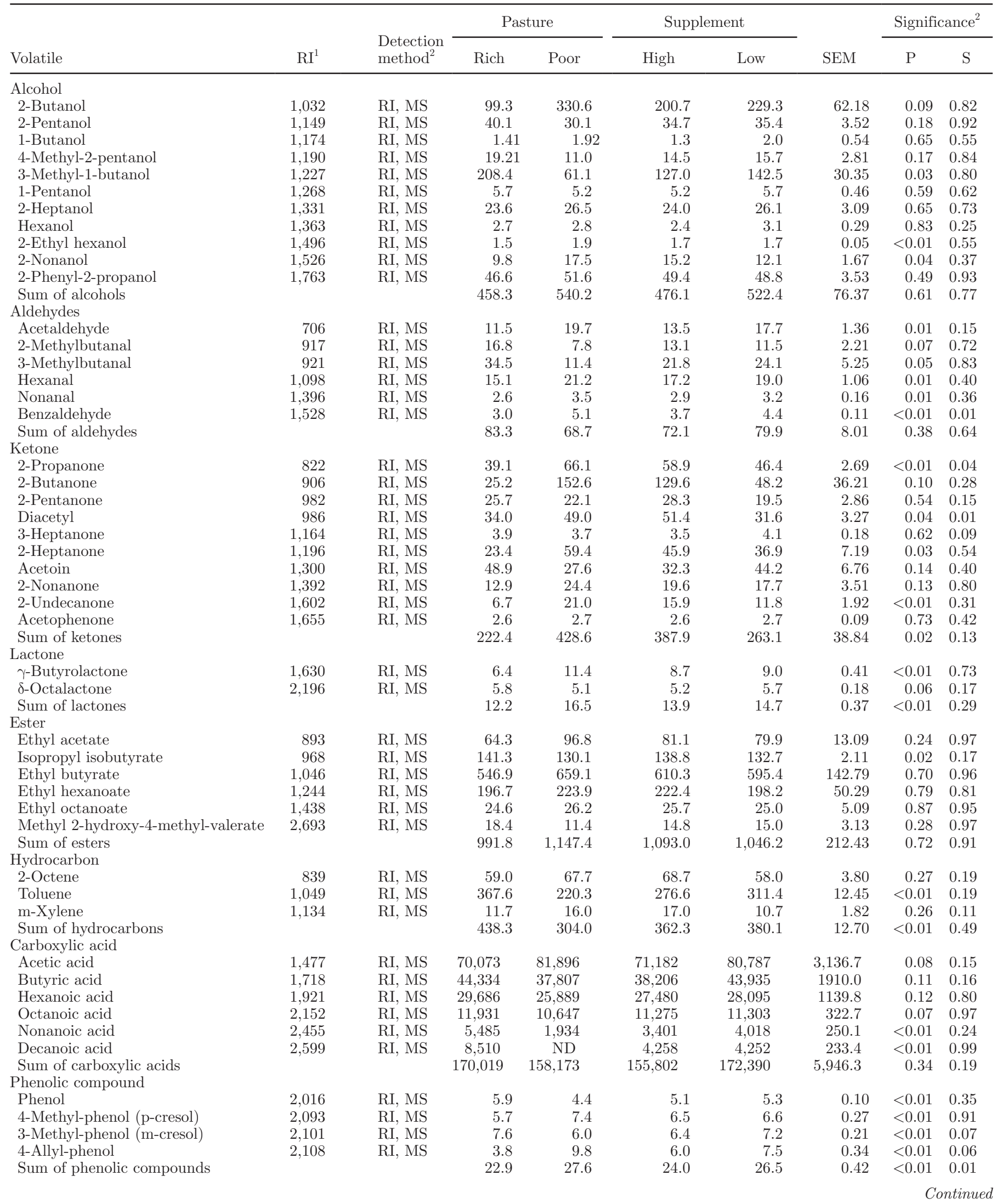


Table 4 (Continued). Volatiles $(\mu \mathrm{g} / \mathrm{kg})$ in experimental cheeses by solid-phase microextraction GC-MS analysis

\begin{tabular}{|c|c|c|c|c|c|c|c|c|c|}
\hline Volatile & $\mathrm{RI}^{1}$ & $\begin{array}{l}\text { Detection } \\
\text { method }^{2}\end{array}$ & \multicolumn{2}{|c|}{ Pasture } & \multicolumn{2}{|c|}{ Supplement } & SEM & \multicolumn{2}{|c|}{ Significance $^{2}$} \\
\hline \multicolumn{10}{|l|}{ Monoterpene } \\
\hline Camphene & 1,071 & RI, MS & 6.2 & 17.9 & 10.8 & 13.4 & 1.41 & $<0.01$ & 0.37 \\
\hline$\beta$-Pinene & 1,108 & RI, MS & 35.3 & 54.9 & 45.5 & 44.7 & 5.35 & 0.09 & 0.95 \\
\hline Sabinene & 1,125 & RI, MS & 10.0 & 10.4 & 11.4 & 9.0 & 0.60 & 0.71 & 0.07 \\
\hline 8-Hydroxylinalool & 1,332 & RI, MS & 12.4 & 17.2 & 15.1 & 14.5 & 1.07 & 0.05 & 0.81 \\
\hline Sum of monoterpenes & & & 108.8 & 205.1 & 160.7 & 153.2 & 10.07 & $<0.01$ & 0.72 \\
\hline \multicolumn{10}{|l|}{ Sesquiterpene } \\
\hline Caryophyllene & 1,597 & RI, MS & 8.4 & 16.7 & 12.7 & 12.4 & 0.80 & $<0.01$ & 0.82 \\
\hline \multicolumn{10}{|l|}{ Sulfur compound } \\
\hline Carbon disulfide & 734 & RI, MS & 21.2 & 26.6 & 26.0 & 21.7 & 2.21 & 0.24 & 0.34 \\
\hline Dimethyl sulfide & 745 & RI, MS & 10.5 & 11.8 & 11.4 & 10.9 & 0.58 & 0.28 & 0.65 \\
\hline
\end{tabular}

${ }^{1} \mathrm{RI}=$ retention index.

${ }^{2} \mathrm{P}=$ pasture type; $\mathrm{S}=$ supplement level.

bitterness of amines (Pinho et al., 2003). Regarding the experimental factors, significant differences were not detected, with the exception of isopropyl isobutyrate, which was slightly higher in cheese from rich pastures.

Three hydrocarbons were identified: 2-octene, toluene, and m-xylene. Among these compounds, toluene was the most present and was significantly higher in cheese from rich pastures. This compound has been reported several times in cheese (Bontinis et al., 2012; Hayaloglu et al., 2013). Some authors have demonstrated that toluene, as well as other benzyl compounds, originates from the degradation of carotene, particularly present in milk from cows grazing on pastures (Villeneuve et al., 2013). Consequently, these differences could be indirectly explained by the different intensity of the yellow color in cheeses, which is linked to the presence of carotene in grass (see Tables 3 and 5).

Carboxylic acids were detected at high concentrations in the experimental cheeses. Acetic, butyric, hexanoic, and octanoic acids were the most abundant detected volatiles. For these compounds, no significant differences were detected. Instead, an effect of the pasture type was found on the concentrations of nonanoic and decanoic acids. Three biochemical pathways are important in the formation of carboxylic acids: proteolysis, lipolysis, and lactose fermentation (McSweeney and Sousa, 2000). Due to their low aroma thresholds, short- and medium-chain carboxylic acids are considered important contributors to the flavor profiles of a wide variety of cheeses (Pinho et al., 2003; Tavaria et al., 2004), and each acid has a characteristic note. For example, acetic acid has a typical vinegary odor, which is sour and sharp, whereas butyric acid has a rancid cheese-like odor and hexanoic acid has a goat-like odor (Curioni and Bosset, 2002). Carboxylic acids are also precursors of other aroma compounds, such as methyl ketones, alcohols, lactones, aldehydes, and esters (Collins et al., 2003).

Phenolic compounds are present in the experimental cheeses in very low quantities, just above the detection limit. Four compounds were detected: phenol, phenol 4-methyl phenol (p-cresol), 3-methyl phenol (mcresol), and 4-allyl-phenol. These compounds appear to positively contribute to aroma at approximately the threshold concentration but tend toward an unpleasant note as their concentration increases. The sensory quality ranges from sharp, medicinal, and sweet to smoky, plastic, and unpleasant sheep-yard notes (Curioni and Bosset, 2002). 4-Methyl-phenol originates by atypical Strecker degradation (McSweeney and Sousa, 2000), was listed as the main odorant of Cheddar, and was thought to be responsible for its cowy-barny note (Urbach, 1997).

Terpenes are important compounds in alpine cheeses (Bosset et al., 1999; Bugaud et al., 2001). These volatile compounds originate from the secondary metabolism of pasture plants and are then transferred to the milk of the grazing cows and finally to the cheese (Mariaca et al., 1997). In all of the Montasio cheeses produced from the milk of the grazing cows, 7 monoterpenes and 1 sesquiterpene were detected. The most abundant monoterpenes were $\alpha$-pinene, $\beta$-pinene, and limonene. 


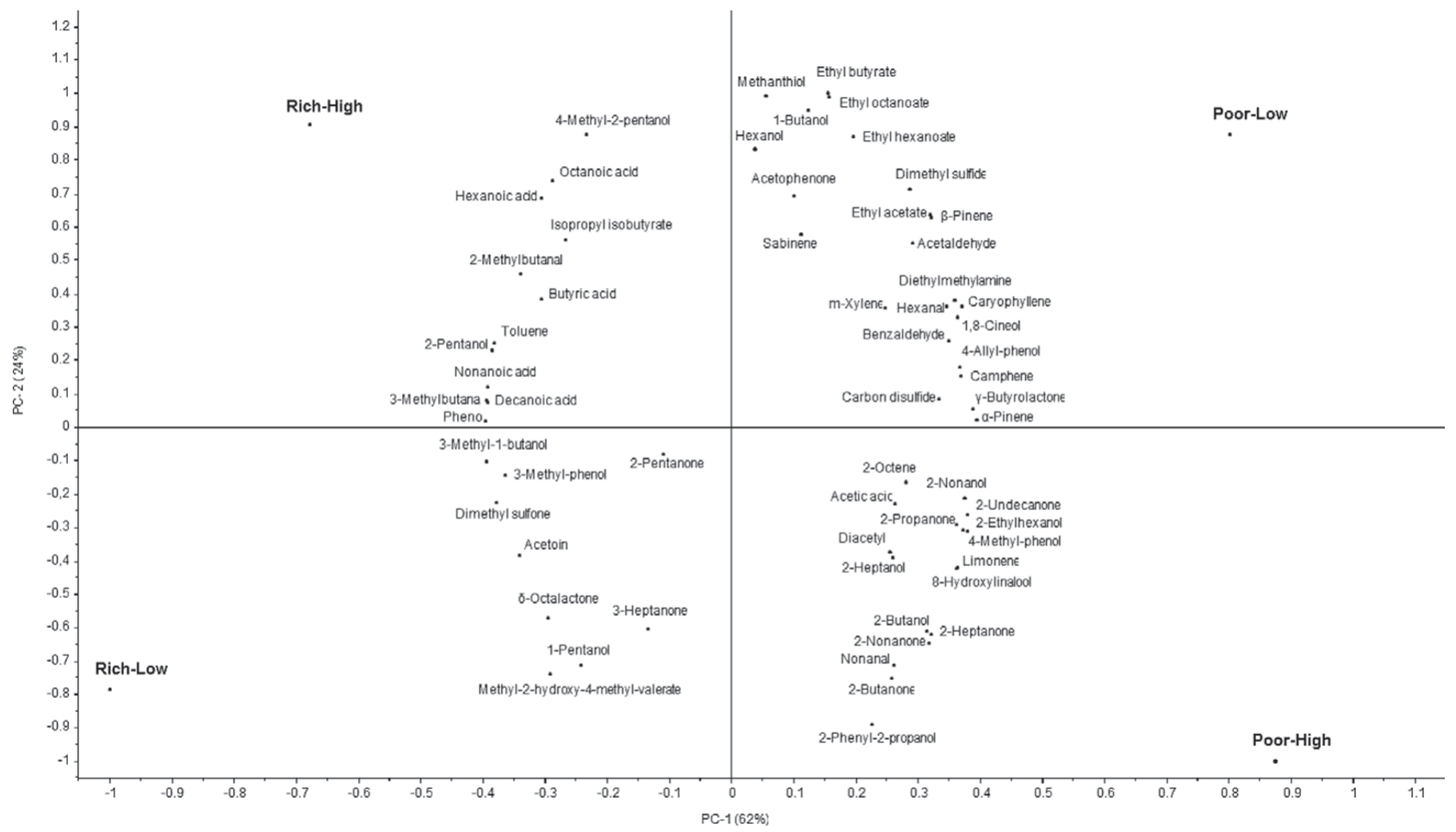

Figure 1. Principal component (PC) analysis of volatile compounds in experimental cheeses (rich: rich pasture; poor: poor pasture; high: high supplement; low: low supplement).

$\alpha$-Pinene and limonene, together with camphene and 1,8-cineol, were significantly more abundant in cheeses produced from cows grazed on poor than on rich pastures. The sum of monoterpenes detected in the cheeses produced from poor pastures was double that of richpasture cheeses, whereas no differences were detected between the cheeses made with different levels of supplementation. Even caryophyllene, which is a unique sesquiterpene in cheeses, appeared at twice the level in poor- as in rich-pasture cheeses. The pasture effect is clearly linked to the different botanical composition. In fact, the poor-pasture cheese is rich in Asteraceae but also in Lamiaceae and Apiaceae, which are botanical families that are particularly rich in terpenes, as reported by Mariaca et al. (1997) and Cornu et al. (2001). Terpenes are important compounds for determining the geographical origin of a cheese type; nonetheless, their importance in the formation of cheese flavor remains controversial (Curioni and Bosset, 2002).

Four sulfur compounds were detected in the experimental cheeses: carbon disulfide, dimethyl sulfide, dimethyl sulfone, and methanethiol. These compounds essentially originate from methionine degradation and result from the cleavage of a bond between carbon and sulfur by a methionine-demethiolase (McSweeney and
Sousa, 2000). Sulfur compounds have strong garlic and very ripe cheese odors that are generally associated with odor notes of cooked cabbage, broccoli, or cauliflower (Kubickova and Grosch, 1998). Furthermore, the perception thresholds of these compounds are low, and these compounds are consequently involved in the final aroma of mold-ripened cheeses. A greater amount of terpenes in cheeses may inhibit the production of these compounds (Bugaud et al., 2001). In our test, this effect did not occur; only dimethyl sulfone was significantly higher in the rich pasture, the poorest in terpenes.

A single amine, diethyl-methyl-amine, was found in the headspace of the experimental cheeses with no significant differences between them. Numerous volatile amines have been reported in Camembert cheese (Molimard and Spinnler, 1996) that is derived from AA decarboxylation (McSweeney and Sousa, 2000).

Figure 1 shows the first 2 components of the principal component analysis. The samples were well separated by the pasture type along the first axis (principal component 1) that explains $62 \%$ of variability. The richpasture cheese was characterized mainly by 3-methyl1-butanol, 3-methyl butanal, 3-methyl phenol, phenol, toluene, dimethyl sulfone, nonanoic acid, and decanoic acid, whereas the poor-pasture cheese was characterized 
Table 5. Sensory panel evaluations of cheeses ${ }^{1}$

\begin{tabular}{|c|c|c|c|c|c|c|c|}
\hline \multirow[b]{2}{*}{ Item } & \multicolumn{2}{|c|}{ Pasture } & \multicolumn{2}{|c|}{ Supplement } & \multirow[b]{2}{*}{ SEM } & \multicolumn{2}{|c|}{ Significance $^{2}$} \\
\hline & Rich & Poor & High & Low & & $\mathrm{P}$ & S \\
\hline \multicolumn{8}{|l|}{ Visual appearance } \\
\hline Color intensity & 62.4 & 50.6 & 58.8 & 54.3 & 4.91 & 0.04 & 0.09 \\
\hline Rind height & 52.9 & 54.9 & 54.4 & 53.4 & 5.52 & 0.65 & 0.82 \\
\hline Eyes, distribution regularity & 41.0 & 45.4 & 46.5 & 39.9 & 7.89 & 0.60 & 0.66 \\
\hline Eyes, diameter & 35.1 & 35.4 & 41.4 & 29.1 & 4.01 & 0.95 & 0.12 \\
\hline Eyes, shape regularity & 46.2 & 47.6 & 44.9 & 48.9 & 6.93 & 0.89 & 0.49 \\
\hline Elasticity & 50.6 & 46.3 & 47.4 & 49.5 & 4.35 & 0.46 & 0.52 \\
\hline \multicolumn{8}{|l|}{ Odor } \\
\hline Milk & 37.9 & 37.2 & 36.7 & 38.3 & 4.72 & 0.77 & 0.25 \\
\hline Cow & 27.2 & 34.9 & 30.6 & 31.4 & 3.69 & 0.04 & 0.72 \\
\hline Sour milk & 43.6 & 42.9 & 42.3 & 44.2 & 4.91 & 0.83 & 0.29 \\
\hline Ammonia & 18.2 & 16.8 & 16.8 & 18.2 & 5.00 & 0.72 & 0.30 \\
\hline Herbage & 14.9 & 18.6 & 17.2 & 16.3 & 5.79 & 0.14 & 0.37 \\
\hline \multicolumn{8}{|l|}{ Taste } \\
\hline Sweet & 36.8 & 40.0 & 39.1 & 37.7 & 2.86 & 0.17 & 0.52 \\
\hline Salty & 40.1 & 38.3 & 37.9 & 40.5 & 2.86 & 0.65 & 0.16 \\
\hline Umami & 31.5 & 34.6 & 31.7 & 34.4 & 4.40 & 0.42 & 0.26 \\
\hline Acid & 16.9 & 18.4 & 17.6 & 17.7 & 4.93 & 0.44 & 0.97 \\
\hline Bitter & 17.3 & 15.6 & 16.4 & 16.4 & 4.22 & 0.33 & 0.98 \\
\hline Pungent & 12.6 & 14.0 & 12.7 & 14.0 & 4.04 & 0.76 & 0.31 \\
\hline \multicolumn{8}{|l|}{ Flavor } \\
\hline Milk & 33.3 & 32.7 & 32.2 & 33.8 & 4.66 & 0.71 & 0.23 \\
\hline Cow & 24.6 & 32.0 & 27.7 & 28.9 & 3.07 & $<0.01$ & 0.65 \\
\hline Sour milk & 35.6 & 37.2 & 37.2 & 35.5 & 4.89 & 0.49 & 0.13 \\
\hline Ammonia & 15.4 & 17.5 & 16.3 & 16.7 & 5.40 & 0.56 & 0.70 \\
\hline Herbage & 14.5 & 17.3 & 16.0 & 15.8 & 5.44 & 0.08 & 0.80 \\
\hline \multicolumn{8}{|l|}{ Texture } \\
\hline Tenderness & 55.5 & 52.2 & 52.8 & 54.9 & 3.37 & 0.33 & 0.59 \\
\hline Adhesivity & 31.6 & 43.4 & 38.4 & 36.7 & 4.40 & 0.03 & 0.70 \\
\hline Creaminess & 38.4 & 51.2 & 45.1 & 44.5 & 4.73 & 0.03 & 0.89 \\
\hline Granules & 35.1 & 28.5 & 30.7 & 32.9 & 3.17 & 0.05 & 0.51 \\
\hline
\end{tabular}

${ }^{1}$ Anchored on a 100-mm unstructured scale.

${ }^{2} \mathrm{P}=$ pasture type; $\mathrm{S}=$ supplement level.

mainly by mono- and sesqui- terpenes, butyrolactone, p-cresol, and ketones. Therefore, the herbage consumed by grazing cows can affect the content of volatiles in cheese. It is well known that this effect can occur in a direct, through the transfer of volatile substances to milk and cheese, or in an indirect manner, as a possible microbial source (Bugaud et al., 2001; Montel et al., 2014). Through a direct manner, terpenes are important, as they have been used to distinguish the cheeses from grass, but also essential to discriminate between the different pastures. In an indirect manner, it is possible to contemplate the compounds originated from microbial metabolism, such as sulfur compounds, alcohols, and aldehydes (McSweeney and Sousa, 2000). The second axis (principal component 2) explains $24 \%$ of the variability but does not allow a clear separation of the samples on the basis of supplement level.

\section{Sensory Panel Evaluation}

Table 5 shows the results of the descriptive sensory evaluation. In general, the panelists described the ex- perimental cheeses with an intense color; small and evenly distributed eyes; an intense odor and flavor of milk-sour, milk, and cow; and a tender and creamy texture. However, the same panelists were unable to detect differences linked to experimental factors among 2 -mo-ripened cheeses. The results show only a slight, though significant, effect of the pasture type on the cow attributes in odor and flavor, which are likely related to certain volatile compounds such as 4-methyl-phenol (Urbach, 1997). In the present trial, the 4-methyl-phenol was detected in very low amounts, but was higher in cheeses produced from the poor pasture. In addition, the pasture type affects certain textural attributes (adhesivity, creaminess, and granules) and the color intensity as perceived by the panelists as well as in the physical analyses (see Table 3).

Several trials have been conducted in Europe, especially in France, Switzerland, and Italy, to study the effect of forage type on the sensory properties of cheeses (Bosset et al., 1999; Carpino et al., 2004; Coulon et al., 2004). The effect of floristic diversity of pastures on cheese aroma and odor are mainly linked to compounds 
originated from the secondary metabolism of the dicotyledons. Among these, terpenes are the most studied and mentioned both for their direct or indirect effect on sensory characteristics and as biomarkers for cheese origin (Martin et al., 2005). In the present trial, despite the fact that mono- and sesqui-terpene concentrations were different in experimental pastures (see Table 4), it was not possible to discriminate the cheeses from a sensory point of view. Although it is possible that the effect of animal diets on sensory properties may vary according to the type of cheese, Tornambé et al. (2008), in a study on the effect of pasture plants essential oils on the sensory properties of Cantal-type cheese, concluded that terpenes had only a small effect on the development of the flavor.

It is also possible that the ripening time was too short to reveal diet effects on the sensory characteristics of experimental cheeses. In effect, other authors have highlighted the absence of differences linked to different botanical composition of the grazed pasture at the early stage of cheese ripening (Cornu et al., 2009; Farruggia et al., 2014). Significant differences were instead observed with ripening times longer than 6 mo (Buchin et al., 1999; Martin et al., 2005).

With regard to supplement level, this did not affect the examined sensory attributes, with the exception of the eye diameter of the cheeses. It is presumable that a maximum supplement level of $3 \mathrm{~kg} /$ head per day (supposedly $15-20 \%$ of the DMI of the cows) is not enough to change the sensory properties of pasture cheeses. The specific effect of supplementation with concentrates of dairy cows grazing on alpine pastures on sensory properties of the cheese has been investigated little.

Lodi et al. (2005), in a study regarding Bitto PDO, an exclusively alpine pasture cheese, demonstrated that the administration of $2.4 \mathrm{~kg} /$ head per day of cerealbased concentrates did not influence the microbiological, chemical, or sensory profiles of the raw milk cheese. More controversial were the results of triangular taste panel made on Nostrano di Primiero cheese produced from the milk of cows grazing in high pastures and subjected to different levels of concentrate (Bovolenta et al., 2008; 2009).

\section{CONCLUSIONS}

The large number of volatile compounds identified in Montasio PDO cheese was most likely due to the cow diet (fresh grass from alpine pastures) and to the traditional cheese-making techniques that were used (raw milk and natural starter). The pasture type is able to modify the volatile profiles of the experimental cheeses, while having a very limited effect as perceived by trained assessors and no effect on chemical composition.
The concentrate supplementation, which is needed to meet the feeding requirements of grazing cows, had no clear effect on either the volatile compounds or physicochemical and sensory properties of the cheeses. Thus, within levels of integration adopted, it is expected not to alter the organoleptic characteristics of the product and can retain the typicity linked to botanical diversity of the grass consumed. This study aimed to contribute to characterize the Montasio cheese produced in the mountain area in accordance also with recent indications of European law, which allows an optional quality term to be used for PDO products with a production chain that takes place entirely in these areas. These results may also be useful in creating conditions to increase the added value of the cheeses from mountain areas, where husbandry is often based on local breeds and where production costs tend to be higher.

\section{ACKNOWLEDGMENTS}

The authors thank the "Centro di Ricerca e Innovazione Tecnologica in Agricoltura" (CRITA, Udine, Italy) for financial support (funds of Friuli Venezia Giulia Region, L.R. n. 26/2005, art. 18) and the Breeders Association of Friuli Venezia Giulia Region (AAFVG, Codroipo, Italy) for technical collaboration.

\section{REFERENCES}

AOAC International. 2000. Official Methods of Analysis. 17th ed. AOAC International, Arlington, VA.

Barham, E. 2003. Translating terroir: The global challenge of France AOC labeling. J. Rural Stud. 19:127-138.

Battaglini, L., S. Bovolenta, F. Gusmeroli, S. Salvador, and E. Sturaro. 2014. Environmental sustainability of Alpine livestock farms. Ital. J. Anim. Sci. 13:431-443.

Baumont, R., J. P. Dulphy, D. Sauvant, F. Meschy, J. Aufrère, and J. L. Peyraud. 2010. Valeur alimentaire des fourrages et des matières premières: Tables et prévision. Pages 149-180 in Alimentation des Bovins, Ovins et Caprins. Tables INRA 2007, mise à jour 2010. Editions Quae, Versailles, France.

Berard, J., F. Bianchi, M. Careri, A. Chatel, A. Mangia, and M. Musci. 2007. Characterization of the volatile fraction and of free fatty acids of "Fontina Valle d'Aosta," a protected designation of origin Italian cheese. Food Chem. 105:293-300.

Boni, R., and I. Seidl. 2012. Alpine products and services-Supply situation in selected Swiss regions. Agrarforschung 3:124-131.

Bontinis, T., H. Mallatou, E. C. Pappa, T. Massouras, and E. Alichanidis. 2012. Study of proteolysis, lipolysis and volatile profile of a traditional Greek goat cheese (Xinotyri) during ripening. Small Rumin. Res. 105:193-201.

Bosset, J. O., B. Jeangros, T. Berger, U. Bütikofer, M. Collomb, R. Gauch, P. Lavanchy, J. Scehovic, J. Troxler, and R. Sieber. 1999. Comparison of Swiss hard cheese Gruyere-type produced in highland and lowland. Rev. Suisse Agric. 31:17-22.

Bovolenta, S., M. Corazzin, E. Saccà, F. Gasperi, F. Biasioli, and W. Ventura. 2009. Performance and cheese quality of Brown cows grazing on mountain pasture fed two different levels of supplementation. Livest. Sci. 124:58-65.

Bovolenta, S., E. Saccà, M. Corazzin, F. Gasperi, F. Biasioli, and W. Ventura. 2008. Effects of stocking density and supplement level on milk production and cheese characteristics in Brown cows grazing on mountain pasture. J. Dairy Res. 75:357-364. 
Bovolenta, S., E. Saccà, M. Corti, and D. Villa. 2005. Effect of supplement level on herbage intake and feeding behaviour of Italian Brown cows grazing on Alpine pasture. Ital. J. Anim. Sci. 4:197-199.

Buchin, S., B. Martin, D. Dupont, A. Bornard, and C. Achilleos. 1999. Influence of the composition of Alpine highland pasture on the chemical, rheological and sensory properties of cheese. J. Dairy Res. 66:579-588.

Bugaud, C., S. Buchin, A. Hauwuy, and J. B. Coulon. 2001. Relationships between flavour and chemical composition of Abondance cheese derived from different types of pastures. Lait 81:757-773.

Carpino, S., S. Mallia, S. La Terra, C. Melilli, G. Licitra, T. E. Acree, D. M. Barbano, and P. J. Van Soest. 2004. Composition and aroma compounds of Ragusano cheese: Native pasture and total mixed rations. J. Dairy Sci. 87:816-830.

Collins, Y. F., P. L. H. McSweeney, and M. G. Wilkinson. 2003. Lipolysis and free fatty acid catabolism in cheese: A review of current knowledge. Int. Dairy J. 13:841-866.

Cornu, A., A. P. Carnat, B. Martin, J. B. Coulon, J. L. Lamaison, and J. L. Berdagué. 2001. Solid-phase microextraction of volatile components from natural grassland plants. J. Agric. Food Chem. 49:203-209.

Cornu, A., N. Rabiau, N. Kondjoyan, I. Verdier-Metz, P. Pradel, P. Tournayre, J. L. Berdagué, and B. Martin. 2009. Odour-active compound profiles in Cantal-type cheese: Effect of cow diet, milk pasteurization and cheese ripening. Int. Dairy J. 19:588-594.

Coulon, J. B., A. Delacroix-Buchet, B. Martin, and A. Pirisi. 2004. Relationships between ruminant management and sensory characteristics of cheeses: A review. Lait 84:221-241.

Curioni, P. M. G., and J. O. Bosset. 2002. Key odorants in various cheese types as determined by gas chromatography-olfactometry. Int. Dairy J. 12:959-984.

De Noni, I., and G. Battelli. 2008. Terpenes and fatty acid profiles of milk fat and Bitto cheese as affected by transhumance of cows on different mountain pastures. Food Chem. 109:299-309.

Dimos, A., G. E. Urbach, and A. J. Miller. 1996. Changes in flavour and volatiles of full-fat and low-fat cheeses during maturation. Int. Dairy J. 6:981-995.

Dovier, S., R. Valusso, M. Morgante, A. Sepulcri, and S. Bovolenta. 2005. Quality differences in cheeses produced by lowland and highland units of the Alpine transhumant system. Ital. J. Anim. Sci. $4: 245-247$.

Drake, M. A. 2007. Invited review: Sensory analysis of dairy foods. J. Dairy Sci. 90:4925-4937.

Endrizzi, I., A. Fabris, F. Biasioli, E. Aprea, E. Franciosi, E. Poznanski, A. Cavazza, and F. Gasperi. 2012. The effect of milk collection and storage conditions on the final quality of Trentingrana cheese: Sensory and instrumental evaluation. Int. Dairy J. 23:105-114.

Farruggia, A., D. Pomiès, M. Coppa, A. Ferlay, I. Verdier-Metz, A. Le Morvan, A. Bethier, F. Pompanon, O. Troquier, and B. Martin. 2014. Animal performances, pasture biodiversity and dairy product quality: How it works in contrasted mountain grazing systems . Agric. Ecosyst. Environ. 185:231-244.

Franciosi, E., F. Gardini, L. Monfredini, G. Tabanelli, A. Fabris, I. Endrizzi, E. Poznanski, F. Gasperi, and A. Cavazza. 2012. Does milk treatment before cheesemaking affect microbial and chemical traits of ripened cheese? Grana Trentino as a case study. J. Dairy Sci. 95:5485-5494.

Goering, H. K., and P. J. Van Soest. 1970. Forage Fiber Analyses (Apparatus, Reagents, Procedures, and Some Applications). Agricultural Handbook. Agricultural Research Service-USDA, Washington, DC.

Gunasekaran, S., and M. M. Ak. 2003. Cheese Rheology and Texture. CRC Press, Boca Raton, FL.

Hauwuy, A., F. Delattre, D. Roybin, and J. B. Coulon. 2006. Consequences of the establishment of cheese-production chains with a PDO denomination: A case study of the northern Alps. Prod. Anim. 19:371-380.

Hayaloglu, A. A., C. Tolu, K. Yasar, and D. Sahingil. 2013. Volatiles and sensory evaluation of goat milk cheese Gokceada as affected by goat breeds (Gokceada and Turkish Saanen) and starter culture systems during ripening. J. Dairy Sci. 96:2765-2780.

Innocente, N., M. Munari, and M. Biasutti. 2013. Characterization by solid-phase microextraction-gas chromatography of the volatile profile of protected designation of origin Montasio cheese during ripening. J. Dairy Sci. 96:26-32.

Innocente, N., P. Pittia, O. Stefanuto, and C. Corradini. 2002. Correlation among instrumental texture, chemical composition and presence of characteristic holes in a semi-hard Italian cheese. Milchwissenschaft 57:204-208.

ISO. 2009a. ISO 22935-1/IDF 099-1: Milk and milk products. Sensory analysis-Part 1: General guidance for the recruitment, selection, training and monitoring of assessors. International Organization for Standardization (ISO), Geneva, Switzerland.

ISO. 2009b. ISO 22935-2/IDF 099-2: Milk and milk products. Sensory analysis - Part 2: Recommended methods for sensory evaluation. International Organization for Standardization (ISO), Geneva, Switzerland.

ISO. 2009c. ISO 22935-3/IDF 099-3: Milk and milk products. Sensory analysis - Part 3: Guidance on a method for evaluation of compliance with product specifications for sensory properties by scoring. International Organization for Standardization (ISO), Geneva, Switzerland.

Kubickova, J., and W. Grosch. 1998. Quantification of potent odorants in Camembert cheese and calculation of their odour activity values. Int. Dairy J. 8:17-23.

Lodi, R., M. Brasca, B. Masa, A. Tamburini, S. Erini, and E. Turchetti. 2005. Effect of supplementation on Bitto chees characteristics. Pages 140-156 in L'alimentazione Della Vacca da Latte al Pascolo. Quaderni SoZooAlp n. 2. SoZooAlp, San Michele all'Adige (TN), Italy.

Lucey, J. A., M. E. Johnson, and D. S. Horne. 2003. Invited review: Perspectives on the basis of the rheology and texture properties of cheese. J. Dairy Sci. 86:2725-2743.

Maifreni, M., M. Marino, P. Pittia, and G. Rondinini. 2002. Textural and sensorial characterization of Montasio cheese produced using proteolytic starters. Milchwissenschaft 57:23-26.

Malossini, F., S. Bovolenta, C. Piras, M. Dalla Rosa, and W. Ventura. 1996. Effect of diet and breed on milk composition and rennet coagulation properties. Anim. Res. 45:29-40.

Mariaca, R. G., T. F. H. Berger, R. Gauch, M. I. Imhof, B. Jeangros, and J. O. Bosset. 1997. Occurrence of volatile mono- and sesquiterpenoids in highland and lowland plant species as possible precursors for flavor compounds in milk and dairy products. J. Agric. Food Chem. 45:4423-4434.

Marino, V. M., I. Schadt, S. Carpino, M. Caccamo, S. La Terra, C. Guardiano, and G. Licitra. 2014. Effect of Sicilian pasture feeding management on content of $\alpha$-tocopherol and $\beta$-carotene in cow milk. J. Dairy Sci. 97:543-551.

Martin, B., I. Verdier-Metz, S. Buchin, C. Hurtaud, and J. B. Coulon. 2005. How do the nature of forages and pasture diversity influence the sensory quality of dairy livestock products? Anim. Sci. $81: 205-212$

McLafferty, F. W. 2006. Wiley Registry of Mass Spectral Data, 8th ed., and NIST Spectral Data CD-ROM. John Wiley \& Sons Inc., Hoboken, NJ.

McSweeney, P. L. H., and M. J. Sousa. 2000. Biochemical pathways for the production of flavour compounds in cheeses during ripening: A review. Lait 80:293-324.

Moio, L., and F. Addeo. 1998. Grana Padano cheese aroma. J. Dairy Res. 65:317-333.

Molimard, P., and H. E. Spinnler. 1996. Review: Compounds involved in the flavor of surface mold-ripened cheeses: Origins and properties. J. Dairy Sci. 79:169-184.

Montel, M. C., S. Buchin, A. Mallet, C. Delbes-Paus, D. A. Vuitton, N. Desmasures, and F. Berthier. 2014. Traditional cheeses: Rich and diverse microbiota with associated benefits. Int. J. Food Microbiol. 177:136-154. 
Nagaraja, T. G. 2012. A microbiologist's view on improving nutrient utilization in ruminants. Pages $135-161$ in Proc. 23rd Ann. Fla. Rumin. Nutr. Symp., University of Florida, Gainesville.

Nozière, P., B. Graulet, A. Lucas, B. Martin, P. Grolier, and M. Doreau. 2006. Carotenoids for ruminants: From forages to dairy products. Anim. Feed Sci. Technol. 131:418-450.

Panseri, S., I. Giani, T. Mentasti, F. Bellagamba, F. Caprino, and V. M. Moretti. 2008. Determination of flavour compounds in a mountain cheese by headspace sorptive extraction-thermal desorption-capillary gas chromatography-mass spectrometry. Food Sci. Technol. Leb. 41:185-192.

Peyraud, J. L., and L. Delaby. 2001. Ideal concentrate feeds for grazing dairy cows - Responses to supplementation in interaction with grazing management and grass quality. Pages 203-220 in Recent Advances in Animal Nutrition 2001. P. C. Garnsworthy and J. Wiseman, ed. Nottingham University Press, Nottingham, UK.

Pillonel, L., S. Ampuero, R. Tabacchi, and J. O. Bosset. 2003. Analytical methods for the determination of the geographic origin of Emmental cheese: Volatile compounds by GC/MS-FID and electronic nose. Eur. Food Res. Technol. 216:179-183.

Pinho, O., I. Ferreira, and M. A. Ferreira. 2003. Quantification of short-chain free fatty acids in "Terrincho" ewe cheese: Intravarietal comparison. J. Dairy Sci. 86:3102-3109.

Polentarutti, M., L. Piasenzotto, G. Comi, L. Conte, and A. Surmely. 2001. Influence of season on raw milk and on Montasio cheese aroma. Ind. Aliment. 409:1331-1342.

Romanzin, A., M. Corazzin, E. Piasentier, and S. Bovolenta. 2013. Effect of rearing system (mountain pasture vs. indoor) of Simmental cows on milk composition and Montasio cheese characteristics. J. Dairy Res. 80:390-399.

Rychlik, M., and J. O. Bosset. 2001. Flavour and off-flavour compounds of Swiss Gruyere cheese. Evaluation of potent odorants. Int. Dairy J. 11:895-901.

Sturaro, E., E. Marchiori, G. Cocca, M. Penasa, M. Ramanzin, and G. Bittante. 2013. Dairy systems in mountainous areas: Farm animal biodiversity, milk production and destination, and land use. Livest. Sci. 158:157-168.

Tavaria, F. K., A. C. Silva Ferreira, and F. Xavier Malcata. 2004. Volatile free fatty acids as ripening indicators for Serra da Estrela cheese. J. Dairy Sci. 87:4064-4072.

Thomsen, M., C. Martin, F. Mercier, P. Tournayre, J. L. Berdagué, T. Thomas-Danguin, and E. Guichard. 2012. Investigating semihard cheese aroma: Relationship between sensory profiles and gas chromatography-olfactometry data. Int. Dairy J. 26:41-49.

Tornambé, G., A. Cornu, I. Verdier-Metz, P. Pradel, N. Kondjoyan, G. Figueredo, S. Hulin, and B. Martin. 2008. Addition of pasture plant essential oil in milk: Influence on chemical and sensory properties of milk and cheese. J. Dairy Sci. 91:58-69.

Tornambé, G., A. Ferlay, A. Farruggia, Y. Chilliard, P. Loiseau, P. Pradel, B. Graulet, B. Chaveau-Duriot, and B. Martin. 2010. Influence of botanical diversity and development stage of mountain pastures on milk fatty acid composition, carotenoids, fat-soluble vitamins and sensory properties. Pages 589-591 in Grassland in a Changing World. Grassland Science in Europe. Vol. 15. H. Schnyder, J. Isselstein, E. Taube, K. Auerswald, J. Schellberg, M. Wachendorf, A. Herrmann, M. Gierus, N. Wrage, and A. Hopkins, ed. Universität Göttingen, Göttingen, Germany.

Urbach, G. 1997. The flavour of milk and dairy products: II. Cheese: contribution of volatile compounds. Int. J. Dairy Technol. 50:7989.

UNI (Ente Nazionale Italiano di Unificazione). 2010. UNI EN ISO 8589: Sensory analysis - General guidance for the design of test rooms. UNI, Milan, Italy.

Villeneuve, M. P., Y. Lebeuf, R. Gervais, G. F. Tremblay, J. C. Vuillemard, J. Fortin, and P. Y. Chouinard. 2013. Milk volatile organic compounds and fatty acid profile in cows fed timothy as hay, pasture, or silage. J. Dairy Sci. 96:7181-7194. 